\title{
Kunst en kinderen
}

"Wat zijn ze schattig en lief", de kindertjes van Millais op het schilderij "De grote passie" dat te zien was op de grote overzichtstentoonstelling in het voorjaar van 2008 in het Van Gogh museum. Vol aandacht kijken ze naar een verzameling opgezette vogels van een oude man, die met een opgezette paradijsvogel in z'n hand in het middelpunt van de belangstelling staat. "Waren ze nog maar zo", zie je het wat oudere publiek denken. Millais beeldde in de portretten van kinderen in de serie 'fancy pictures', waar het schilderij "De grote passie" er één van is, het ideale kind uit. Paradijselijke beelden van kinderen uit de betere klasse, met de onschuld en ingetogen vitaliteit die daarbij horen. Het schilderij "De grote passie" laat ook het respect zien dat kinderen voor de oudere man hebben; het is bijna een personificatie van Jezus en zijn discipelen. Maar op een schilderij van zijn eigen kinderen laat Millais een ander beeld zien. Drie prachtige dochters, mooi uitgedost, maar wordt de oudste nog wat lieflijk neergezet, de twee jongste dochters worden afgebeeld als snibbige bijdehante jongedames, die ons licht verveeld aankijken. Hier schemert het werkelijke kind door de ogen van de kunstenaar en dat maakt dit schilderij ook veel sterker. Hoe dichter Millais bij zijn onderwerp stond, hoe beter hij schilderde, getuige ook de portretten van vrienden en familieleden.

Dit doet denken aan het prachtige schilderij van Velasquez, die de Spaanse prinses Infanta Maria Theresa in 1658 geschilderd heeft. De mooie papillotten in het haar verbloemen niet dat hij een ver- wend nest schilderde, dat je met een licht arrogante blik aankijkt. Toch zien wij ook nog het kind en die ambivalentie in het waarnemen maakt, naast de technische kwaliteiten, het schilderij tot één van de hoogtepunten van Velasquez' oeuvre in The Metropolitan Museum of Art in New York (www.metmuseum.org).

Kinderen worden veel geschilderd en één blik op de muren van vrienden en familieleden is voldoende om deze stelling te bevestigen. Zelden word je door deze portretten geroerd en de reden is dat de meeste schilders niet in staat zijn om de wezenlijke trekken van een kind af te beelden. Die eigenschappen die samenhangen met erfelijkheid, leeftijd, opvoeding en vitaliteit, en die zo kenmerkend zijn voor een kind, zijn toch moeilijk te vatten.

Jaren geleden bevond ik mij op het strand in Nerja (Spanje). Niets leuker dan om je heen te kijken en te zien hoe al die levens om elkaar heen drentelen. Mijn blik werd getroffen door een gezin, met wat oudere ouders. Moeder stapte zo nu en dan het strand op met de baby en vertrok na enige tijd weer naar hun appartement. Vader spelde de krant uit en z'n oudste dochtertje van ongeveer zes jaar vermaakte zich prima. Zo nu en dan stapte ze op andere mensen af, liep dan weer terug, schepte wat zand, liep langs de rand van de zee en dat alles onder de waakzame blik van vader. Liep ze te ver weg, dan liep hij rustig naar haar toe en voerde haar weer binnen de cirkel van het toelaatbare. Even trokken ze samen weer op, maar dan begon het spel weer. Het tekenen van dit prachtige beeld van dit ex- 
Kunst en kinderen $\mid$ W. Kuis

plorerende kind in die veilige rustige omgeving is een uitdaging. Ik realiseerde me op dat moment hoe moeilijk het is om juist dit hele beeld in dit kind samen te ballen (zie afbeelding 1).

Op een grote overzichtstentoonstelling van de schilder Luc Tuymans (München, 2008) staat een intiem schilderij, dat tot de hoogtepunten van de tentoonstelling behoort. Er is een jongetje in uniform op te herkennen, dat op een jezuïetencollege gezeten heeft (zie afbeelding 2). Het schilderij heet "Valley" en is geschilderd naar een 'still' uit de film "Valley of Doomned" uit de jaren zestig. Het werk is feilloos van sfeer en geeft de effecten van een strenge, repressieve opvoeding op een kindergezicht weergaloos weer. Ook hier schemert door de angstige en serieuze blik het kind door. Dat maakt het beeld kwetsbaar en broos. Wat je raakt in dit schilderij is de compassie die de schilder voor dit onderwerp heeft. Hij dringt diep door in de psyche van dit kind, maar wel gericht op dat overheersende aspect van die drukkende sfeer van de jezuïetenopleiding.

Het kan natuurlijk ook anders. Neem een schilder als Baltus of een moderne kunstenaar als Kiki Lamers. Ze schilder(d)en kinderen vanuit een volwassen blik. Prachtige portretten, maar waar blijft de essentie van dit kind? Waarom maken deze portretten zo'n lege indruk? Het gaat hier niet om het feit dat beide schilders wel eens verweten is kinderen pornografisch te schilderen, dat is een belachelijke aantijging, maar meer om het feit dat hier een zekere ongelijkheid gecreëerd is. De volwassene, die kinderen observeert, maar ze zonder communicatie neerzet. Dat levert mooie schilderijen op. Beide schilders zijn uiterst succesvol, maar de ontroering blijft uit. Het kijken wordt een esthetisch plezier, maar het beeld blijft verder gesloten. Dat dit de fantasie prikkelt en het esthetisch gevoel raakt, blijkt wel uit de populariteit van beide schilders. Op een andere manier kom je weer uit bij de 'fancy pictures', de kinderportretten van Millais. Ook deze portretten laten niet meer toe dan het oppervlak toestaat.

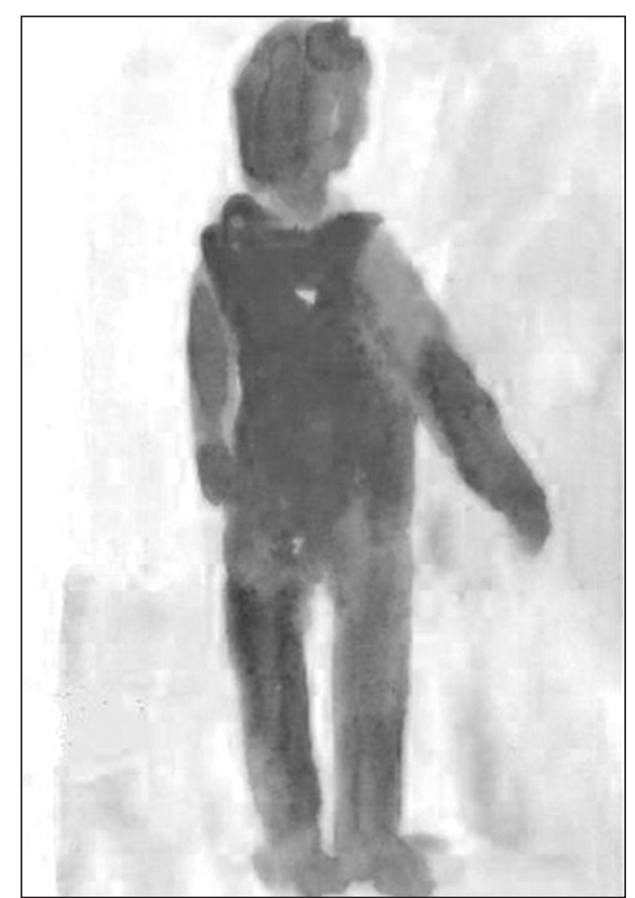

Afbeelding 1. Aquarel van de hand van W. Kuis.

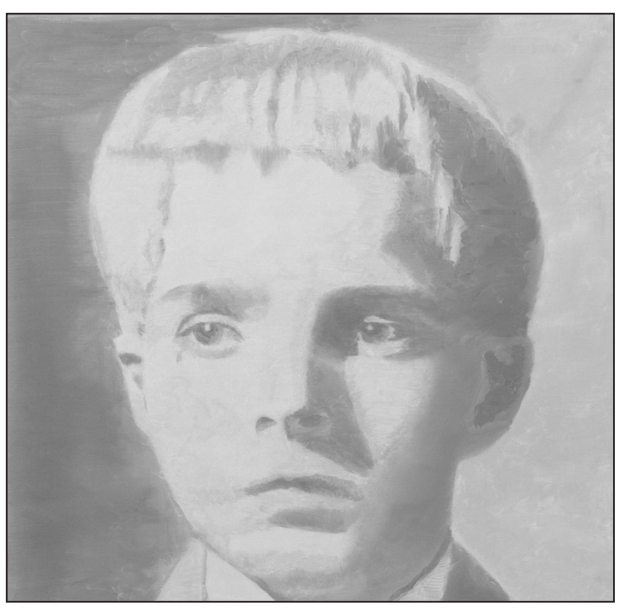

Afbeelding 2. Valley - Luc Tuymans. 


\section{Kunst in de opleiding geneeskunde}

Het is jammer dat in de geneeskunde niet vaker kunst gebruikt wordt om de essentie van de ziekte weer te geven. Ook in de kindergeneeskunde zijn daar prachtige voorbeelden van. De schilderingen van Edvard Munch laten genadeloos de desastreuze effecten van tuberculose zien op kinderen zoals in het portret "The sick child" uit 1896 dat te zien is in The Museum of Modern Art in New York (www.MoMa.org). Het schilderij "De Convalescent" van Helene Schjerfbeck dat in het Ateneum Art Museum in Helsinki hangt, laat een kwetsbaar kind zien dat voor het eerst weer even op is na het doormaken van een (ernstige) infectie (www.ateneum.fi).

Een merkwaardig schilderij is "Amore Dormiente" van Caravaggio, geschilderd in \pm 1608 op Malta (zie Afbeelding 3). Waarschijnlijk heeft hij het kind geschilderd, toen het al overleden was. Klinisch past het beeld bij een ernstige vorm van kinderreuma, de zogenaamde systemische juveniele idiopathische arthritis. Op het schilderij zie je de zwelling van de gewrichten, de contracturen, onderontwikkeling van de kaak en de ernstige groeistoornis die als gevolg van de ziekte opgetreden is. Het kind is waarschijnlijk overleden aan een pericarditis, wat meestal de doodsoorzaak van deze ziekte was. Waarom Caravaggio dit ernstig beschadigde kind als Amore Dormiente schilderde, zal altijd wel een onopgeloste vraag blijven. Hij zag in dit kind een schoonheid, en dit weet hij ook op de toeschouwer over te brengen. Het kind zelf verdwijnt onder de last van de symboliek, maar daar was het de schilder niet om te doen.

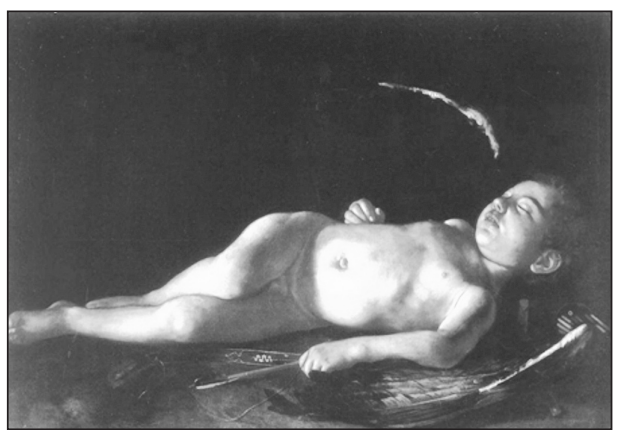

Afbeelding 3. Amore dormiente - Caravaggio.

Het schilderen van kinderen stelt hoge eisen aan het inlevingsvermogen van de schilder. Grote kunstenaars zijn in staat geweest om de wereld van het kind op een onnavolgbare wijze weer te geven. Deze werken blijven in je geheugen gegrift en leren je vaak meer over de wereld van kinderen dan een wetenschappelijk betoog of artikel. Het zou goed zijn om studenten, die op een of andere manier professioneel bij kinderen betrokken zijn, meer te confronteren met kunst over kinderen, louter en alleen om hen te leren kijken. De phenotypische karakteristieken van een ziekte komen vaak beter over in een kunstwerk, dan in professionele afbeeldingen. Kunstenaars zijn vaak beter in staat om de impact van ziekte op een kind tot uitdrukking te brengen.

Wietse Kuis

De auteur:

Prof. dr. W. Kuis is kinderarts en werkzaam in het UMC Utrecht, lokatie Wilhelmina Kinderziekenhuis. 